\title{
Using the SERVQUAL Model in Prediction of Customer Satisfaction in Czech Fitness Centres
}

\author{
Jan Šíma, Tomáš Ruda \\ Charles University, Prague, Czech Republic
}

\begin{abstract}
The aim of this study is to examine the applicability of the SERVQUAL model which predicts customer satisfaction in the area of fitness in the Czech Republic. Three hundred and fifty-six respondents from three Prague fitness centres and one fitness centre in Př́bram, Central Bohemia, participated in the research. Service quality was measured by the SERVQUAL model, and satisfaction was measured by the Oliver scale. Two files of data were gathered: the first with the aim to find out customer expectation with which customers attend their fitness centre; and the second with the aim to find out their quality perception. A difference of measured values was set and these results were subsequently used to predict customer satisfaction. The results of the study do not support the usage of the SERVQUAL model to predict customer satisfaction in fitness centres throughout the Czech Republic. The results indicate the need for another study of factors that determine customer satisfaction in the area of fitness in the Czech Republic.
\end{abstract}

Keywords: fitness, services, quality, satisfaction, SERVQUAL, Oliver scale

\section{Introduction}

Service quality, customer satisfaction, and their loyalty are generally considered important questions in most sectors of services including sports (Crompton, MacKay, \& Fesenmaier, 1991; Guest \& Taylor, 1999; McDonald, Sutton, \& Milne, 1995; Robinson, 1995; 1999; 2006; Wright, Duray, \& Goodale, 1992). High quality is a way to gain new customers and keep the existing ones. It is mainly in the area of fitness where sports institutions are dependent on regular and frequently repeating attendance of their members.

Literature of management suggests many approaches and concepts to evaluate service quality in the area of fitness (Cronin \& Taylor, 1994; Howat, Absher, \& Milne, 1996; Kouthouris \& Alexandris, 2005; Tsitskari, Tsiotras, \& Tsiotras, 2006; Yong, 2000). There are also many different concepts, in which the term "service quality" should be understood with regard to sports (Chang, Chen, \& Hsu, 2002; Javadein, Khanlari, \& Estiri, 2008; Shonk \& Chelladurai, 2008; Śíma \& Ruda, 2011).

The consensus on this can be found only in the fact that one important aspect in evaluating or improving service quality is determining the quality core or their dimensions (Brady \& Cronin, 2001; Chelladurai \&

Acknowledgements: This research was supported by the Grant Agency of Charles University, Project 267811 measuring sport services quality in fitness industry. This research was supported by the Grant Agency of Charles University, Project 575612 Standardization of the questionnaire SERVQUAL, measuring the quality of sport and physical education services in institutions dealing with the preschool education in the Czech Republic.

Dr. Jan Šíma, Ph.D., Faculty of Physical Education and Sport, Charles University, Prague, Czech Republic.

Tomáš Ruda, Mgr., Faculty of Physical Education and Sport, Charles University, Prague, Czech Republic.

Correspondence concerning this article should be addressed to Tomáš Ruda, Faculty of Physical Education and Sport, Charles University, José Martího 269/31, 16252 Prague 6-Veleslavin, Czech Republic. 
Chang, 2000; U. Lehtinen \& J. R. Lehtinen, 1991; Parasuraman, Zeithaml, \& Berry, 1988). However, these dimensions must always be adapted to that current environment where service quality is observed (Brady, 1997; Yong, 2000).

Services in the area of fitness have their specifics as well. Recipients of these services usually participate actively in the progress of service provision. They frequently choose how services are provided to them. It is not unusual that customers only use sports facilities of the provider without even meeting them. However, if they meet them, the effect of the provider can also have an educational character (Chang \& Chelladurai, 2003; Chelladurai, Scott, \& Haywood-Farmer, 1987).

Evaluating the level of service quality of sports services is generally problematic. Sports organizations have a range of characteristics which distinguish them from other service organizations. Mainly, household budgets for sports services are left to open consideration and can be considered luxurious. Secondly, customers usually take part in sports organizations in their free time, and finally, it is about their emotional investment to sports organization, such as support a sports team, be its member or go exercising, and improve their physical condition. These factors can, according to Robinson (2006), lead to much higher demands or expectations from sports organizations than from other service providers.

\section{Relationship Between Service Quality and Customer Satisfaction}

The influence of service quality on customer satisfaction has become a frequently discussed topic. Nowadays, it has been understood that service quality directly influences customer satisfaction. It is probably that customers with positive perception of service quality show high level of satisfaction (Caruana, 2002; Cronin \& Taylor, 1992; Spreng \& Chiou, 2002; Spreng \& McKoy, 1996; Woodside, Frey, \& Daly, 1989).

In spite of the fact that some authors use terms "service quality" and "customer satisfaction" alternatively, most authors agree that both constructions are different, even though interconnected (Parasuraman, Zeithamlová, \& Berry, 1988; Spreng \& Mackoy, 1996; Taylor \& Baker, 1994). According to Zeithamlová and Bittner (2003), "satisfaction" is a broader term than "service quality". In fact, it includes both cognitive evaluation and effect evaluation (functional), whereas service quality evaluation is a procedure exclusively cognitive (Tian-Cole \& Crompton, 2003). Many studies from the area of service marketing consider these two constructions mutually strongly interconnected (Alexandris, Dimitriadis, \& Kasiara, 2001; Caruana, 2002; Spreng \& Chiou, 2002).

Several authors have examined the immediate influence of service quality and customer satisfaction in the area of fitness. It has been confirmed by some of them on the basis of their researches (Javadein, Khanlari, \& Estiri, 2008, Murray \& Howat, 2002; Shonk \& Chelladurai, 2008); others say that any direct connections cannot be fully confirmed (Kouthouris \& Alexandris, 2005; Yong, 2000).

This research in the area of fitness in the Czech Republic should contribute to the initiated discussion.

\section{Aim}

The aim of the study was to determine to what extent it is possible to predict satisfaction on the basis of service quality evaluation with the help of the Czech version of the SERVQUAL questionnaire. A partial aim was then to identify possible insufficiencies in services provision in the area of fitness.

\section{Methods}

There were in total 356 customers $(N=356)$ of four fitness centres in Prague and Central Bohemia 
participating in the research. They filled in questionnaires without any help of inquirers. The questionnaire consisted of items trying to find out customer expectation and their quality perception, and also three separate questions evaluating customer satisfaction with their participation in fitness programmes. The questionnaire for customers combined the SERVQUAL method to determine service quality and the Oliver scale to determine customer satisfaction. Demographic characteristics are shown in Table 1.

Table 1

Demographic Characteristics of the Sample

\begin{tabular}{llllll}
\hline Gender & $N$ & Percentage (\%) & Age groups & $N$ & Percentage (\%) \\
\hline Males & 162 & 45.5 & Less than 20 years old & 16 & 4.5 \\
Females & 194 & 54.5 & $21-30$ years old & 112 & 31.5 \\
& & $31-40$ years old & 156 & 43.8 \\
& & $40-50$ years old & 47 & 13.2 & 5.9 \\
& & $50-60$ years old & 21 & 1.1 \\
\hline
\end{tabular}

\section{Service Quality Evaluation}

The SERVQUAL method comes out of an assumption that service quality is determined by five dimensions: reliability, assurance, tangibles, empathy, and responsiveness approach. Reliability expresses the ability to provide the service promised reliably and accurately. Assurance expresses customer conviction that they will receive the services they expect. Tangibles express physical environment of the organization, such as the interior, facilities, equipment, and communication materials. Empathy expresses care and individual attention of the services providers' employees to customers. Finally, responsiveness reflects the willingness to help customers and provide them with a quick service. Each dimension is evaluated by four or five indicators, which were items in the questionnaire for customers of the fitness centre. The questionnaire has in total $2 \times 22$ items. The first set of questions evaluates customer expectation; the second is how customers perceive the quality of services provided. In both cases, customers express their agreement/disagreement within the Likert scale from 1 to 7 where 1 represents "Strongly disagree" and 7 represents "Strongly agree".

The aim of the SERVQUAL questionnaire is to identify gaps between customer satisfactions and how customers, even subjectively, perceive the service provided. This way of service quality measuring is based on an assumption that a customer will only be happy when the service provided fulfils his or her expectations. These expectations of fitness centres customers vary; therefore, it is not unusual if the same service is evaluated differently.

\section{Customer Satisfaction Evaluation}

Satisfaction was measured by three indicators; (items in the questionnaire) borrowed from the satisfaction evaluation method created by Oliver (1980). Individual statements in the questionnaires were the following: "I am satisfied with my decision to attend this fitness centre", "I am satisfied with the choice of movement activity I am doing here", and "I am convinced that these movement activities can help me achieve my goals". Altoge ther with other statements, even with these fitness centres, customers expressed the extent of their agreement on the Likert scale from 1 = "Strongly disagree" to 7 = "Strongly agree". 
Table 2

Descriptive Statistics and Reliability Analysis for the Service Quality Expectation, Service Quality Perception and Satisfaction

\begin{tabular}{lllll}
\hline & Number of items & Mean & Standard deviation & Coefficient alpha \\
\hline Service quality expectation & & & & 0.73 \\
Reliability & 5 & 6.12 & 0.87 & 0.81 \\
Assurance & 4 & 6.33 & 0.82 & 0.68 \\
Tangibles & 4 & 5.84 & 1.06 & 0.85 \\
Empathy & 5 & 6.05 & 0.79 & 0.81 \\
Responsiveness & 4 & 6.44 & 0.68 & 0.70 \\
Service quality perception & & & & 0.76 \\
Reliability & 5 & 5.51 & 0.91 & 0.53 \\
Assurance & 4 & 5.77 & 0.84 & 0.81 \\
Tangibles & 4 & 6.09 & 1.12 & 0.84 \\
Empathy & 5 & 5.36 & 0.84 & 0.97 \\
Responsiveness & 4 & 5.90 & 0.66 & 0.85 \\
Satisfaction & 3 & 6.64 & & \\
\hline
\end{tabular}

\section{Results}

An average score in five followed characteristics was calculated, always for expectation and for service quality perception. Regarding customer expectation, the results showed that the highest customer expectation is connected with responsiveness of employees (6.44). They mainly expect that the fitness centres employees will always be willing to help customers and provide them with a quick service. The lowest expectation is within tangibles (5.84). It turned out that customers do not care so much about modern equipment of the fitness centre. More important is the approach of the fitness centre employees. Therefore, they are more critical. Average figures of tangibles quality evaluation (6.09) surpassed customer expectation (5.84) and it is therefore possible to say that quality perception of organization environment surpassed customer expectation. Other characteristics observed showed opposite results. The worst evaluated was employees' empathy (5.36), meaning their empathizing to the needs of customers and the individual attention paid to them.

It was important to identify gaps in individual characteristics of service quality and focus on room for possible improvement of the quality of services provided. Determining the size of a gap was done as a difference between average figures of customer quality perception and their satisfaction. Negative figures expressed room for services improvement because customer expectation was higher than quality perception. These figures were measured within reliability (-0.61), assurance (-0.56), empathy (-0.69), and responsiveness $(-0.54)$. Positive figures expressed sufficient service quality because customer quality perception surpassed their expectations. These figures were measured within tangibles $(0.25)$.

From the results mentioned, it would be possible to conclude that the biggest "problem" customers see is how employees empathize to their needs - in this case, the gap was the biggest (-0.69). However, such an interpretation of results would be misleading. It is necessary to considered that each characteristic of service quality observed is differently important for customers. That was the reason why customers were, in the end, asked to divide an imaginary 100 points among individual characteristics according to their importance. These average figures were then used to multiply the gaps. 
The results in Table 3 clearly show that the biggest gap is within reliability - characteristics expressing customer conviction that the service will be done as promised. After the scale of importance of individual characteristics was taken into consideration, the gap reached the resulting figure of -17.08 .

Table 3

Scores and Differences Between Quality Expectations and Perceptions Scales

\begin{tabular}{llllll}
\hline $\begin{array}{l}\text { Service quality } \\
\text { factor }\end{array}$ & $\begin{array}{l}\text { Service quality } \\
\text { perception } \\
\text { (mean) }\end{array}$ & $\begin{array}{l}\text { Service quality } \\
\text { expectation } \\
\text { (mean) }\end{array}$ & $\begin{array}{l}\text { Differences } \\
\text { between factor } \\
\text { scores } \\
\text { (mean) }\end{array}$ & $\begin{array}{l}\text { Scale of importance } \\
\text { (rounded, in } \\
\text { percents) }\end{array}$ & $\begin{array}{l}\text { Resulting differences } \\
\text { between factor scores }\end{array}$ \\
\hline Reliability & 5.51 & 6.12 & -0.61 & 28 & -17.08 \\
Assurance & 5.77 & 6.33 & -0.56 & 23 & -12.88 \\
Tangibles & 6.09 & 5.84 & 0.25 & 14 & 3.5 \\
Empathy & 5.36 & 6.05 & -0.69 & 17 & -11.73 \\
Responsiveness & 5.90 & 6.44 & -0.54 & 18 & -9.72 \\
\hline
\end{tabular}

Even though negative gaps were identified within most observed service quality characteristics, service quality was perceived quite highly — on the seven-grade sale, it was in the average of 5.726. Therefore, it is impossible to evaluate the quantity of services provided as low-quality with respect to low figures of gaps. It is only possible to claim that customer expectation was neither fulfilled nor surpassed. However, this does not mean that customers are not satisfied. As Table 4 shows the average figure expressing customer satisfaction is 6.64. This figure expresses the fact that the majority of customers indicated on the seven-grade scale the maximal possible satisfaction with their decision to attend "their" fitness centre. Most customers are also fully satisfied with their movement activity choice and are convinced that by doing this activity, they will achieve their goals. The most frequent are lose weight, shape up, and keep or improve their physical condition.

Table 4

Mean Scores of Service Quality Expectation, Service Quality Perception and Satisfaction

\begin{tabular}{llll}
\hline & Number of items & Mean & Coefficient alpha \\
\hline Service quality expectation & 22 & 6.16 & 0.78 \\
Service quality perception & 22 & 5.73 & 0.73 \\
Satisfaction & 3 & 6.64 & 0.85 \\
\hline
\end{tabular}

The results mentioned clearly show that even though customer expectation was not completely fulfilled, customers are highly satisfied with services provided. The average figure on the seven-grade scale shows even higher figures than the average figure of quality perception by fitness centres customers is.

\section{Discussion and Conclusion}

The aim of this study was to examine the figures of service quality in relation to possible customer satisfaction prediction in the area of four Czech fitness centres. Service quality in sports and fitness is, according to many authors, the key factor for customer satisfaction (Howat, Murray, \& Crilley, 1999; Murray \& Howat, 2002; Tsuji, Bennet, \& Zhang, 2007; Shonk \& Chelladurai, 2008; Alexandris, Zahariadis, Tsorbatzoudis, \& Grouios, 2008). This fact can also be logically assumed. Customers will be satisfied if services provided are of high quality, and on the contrary, they will probably not be satisfied with services that cannot be considered first-rate. This statement is not disproved by our study. Fitness centre customers 
subjectively consider provided services first-rate and that is apparently the reason why they are also satisfied with their decision to attend the fitness centre. They are also satisfied with the choice of movement activity and are convinced that these movement activities can help them achieve their goals.

However, professional literature also defines satisfaction as a difference between customer expectation and service quality perception (Parasuraman, Zeithaml, \& Berry, 1985; Bronin \& Taylor, 1994; Wisniewski, 2001; Kotler \& Keller, 2009), where a satisfied customer is that person whose expectations are fulfilled or even surpassed. Authors of the SERVQUAL method also prefer such a perception of customer satisfaction. Nevertheless, our study has not come up with any evidence that the SERVQUAL method is a suitable method for customer satisfaction prediction. Even though customer satisfaction was not fulfilled within most of indicators observed, customers were mostly satisfied and in the majority of cases they even marked the utmost figure expressing maximal satisfaction on the Likert scale.

Results of this study call the universal usage of the SERVQUAL model into question similarly to how some previous studies had already done (Bronin \& Taylor, 1994; Brady \& Cronin, 2001). The SERVQUAL model was developed and initially tested in the area of banks and health centres. However, the area of fitness is specific. One of its specificities is a fact that (unlike banks and health centres) we attend fitness centres voluntarily with pleasure and mostly experience nice feelings, such as fun, experience, and enjoyment. Another fact is that if customers were not satisfied with services provided, they would probably change the service provider or would stop using fitness services. The respondents approached by this research logically belong to the group of satisfied customers who have no reason to change their service provider. This confirms the assumption that customers will be satisfied with their decision to attend "their" fitness centre regardless service quality evaluation, or rather size of gaps between their expectations and service quality perception.

The results discovered indicate that the SERVQUAL model cannot serve as a predictor of customer satisfaction in the area of Czech fitness centres but can "only" serve as a tool to identify negative gaps as room for possible improvement of provided services.

\section{References}

Alexandris, K., Dimitriadis, N., \& Kasiara, A. (2001) The behavioral consequences of perceived service quality: An exploratory study in the context of private fitness clubs in Greece. Journal of Sport Management, 4, 280-299.

Alexandris, K., Zahariadis, P., Tsorbatzoudis, C., \& Grouios, G. (2008). An empirical investigation of the relationships among service quality, customer satisfaction and psychological commitment in a health club context. European Sport Management Quarterly, 4(1), 36-52.

Brady, M. K. (1997). Re-conceptualizing perceived service quality: Hierarchical model (Unpublished doctoral dissertation, Florida State University).

Brady, M. K., \& Cronin, J. J. (2001). Some new thoughts on conceptualizing perceived service quality: A hierarchical approach. Journal of Marketing, 65(3), 34-49.

Caruana, A. (2002). The effects of service quality and the mediating role of customer satisfaction. European Journal of Marketing, 36(7), 1-14.

Chang, C. M., Chen, C. T., \& Hsu, C. H. (2002). A review of service quality in corporate and recreational sport/fitness programs. The Sport Journal, 5(3), 1-10.

Chang, K., \& Chelladurai, P. (2003). System-based quality dimension in fitness services: Development of the scale of quality. The Service Industries Journal, 23(5), 65-83.

Chelladurai, P., \& Chang, K. (2000). Targets and standards of quality in sport services. Sport Management Review, 3(1), 1-22.

Chelladurai, P., Scott, F. L., \& Haywood-Farmer, J. (1987). Dimension of fitness services: Development of a model. Journal of Sport Management, 1(1), 159-172. 
Crompton, J. L., MacKay, K., \& Fesenmaier, D. R. (1991). Identifying dimensions of service quality in public recreation. Journal of Park and Recreation Administration, 9(3), 15-27.

Cronin, J., \& Taylor, S. (1992). Measuring service quality: A reexamination and extension. Journal of Marketing, 56(3), 55-68.

Cronin, J., \& Taylor, S. A. (1994). SERVPERF versus SERVQUAL: Reconciling performance based and perceptions-Minus-Expectations measurement of service quality. Journal of Marketing, 58(1), 125-131.

Guest C., \& Taylor P. (1999). Customer oriented public leisure services in the United Kingdom. Managing Leisure, 4(2), 94-106.

Hennig-Thurau, T. (2004). Customer orientation of service employees: Its impact on customer satisfaction, commitment and retention. International Journal of Service Industry Management, 15(5), 460-478.

Howat, G., Absher, J., \& Milne, I. (1996). Measuring customer service quality in sport and leisure centres. Managing Leisure, 1(2), 77-89.

Howat, G., Murray, D., \& Crilley, G. (1999). The relationships between service problems and perceptions of service quality, satisfaction, and behavioral intentions of Australian Public Sports and Leisure Center customers. Journal of Park and Recreation Administration, 17(2), 42-64.

Javadein, S. R. S., Khanlari, A., \& Estiri M. (2008). Customer loyalty in the sport services industry: The role of service quality, customer satisfaction, commitment and trust. International Journal of Human Science, 5(2), 1-19.

Kotler, P., \& Keller, K. L. (2009). Marketing management (13th ed.). Upper Saddle River, NJ: Prentice-Hall.

Kouthouris, C., \& Alexandris, K. (2005). Can service quality predict customer satisfaction and behavioral intentions in the sport tourism industry? An application of the SERVQUAL model in an outdoors setting. Journal of Sport Tourism, 10(2), 101-111.

Lehtinen, U., \& Lehtinen, J. R. (1991). Two approaches to service quality dimensions. The Services Industries Journal, 11(3), 287-303.

McDonald, M., Sutton, W., \& Milne, G. (1995). TEAMQUAL: Measuring service quality in professional team sports. Sport Marketing Quarterly, 4(2), 9-15.

Murray, D., \& Howat, G. (2002). The relationships among service quality, value, satisfaction, and future intentions of customers at an Australian sports and leisure centre. Sport Management Review, 5(1), 25-43.

Oliver, R. (1980). A cognitive model of the antecedents and consequences of satisfaction decisions. Journal of Marketing Research, 17(4), 460-469.

Parasuraman, A., Zeithaml, V. A., \& Berry, L. L. (1985). A conceptual model of service quality and its implication for future research. Journal of Marketing, 49(Fall), 41-50.

Parasuraman, A., Zeithaml, V. A., \& Berry, L. L. (1988). SERVQUAL: A multiple-item scale for measuring consumer perceptions of service quality. Journal of Retailing, 64(1), 12-40.

Robinson, L. (1995). Quality management: An investigation into the use of quality programmes in local authority sport and leisure facilities. Melton Mowbray: Melton Mowbray Institute of Sport and Recreation Management.

Robinson, L. (1999). Following the quality strategy: The reasons for the use of quality management in UK public leisure facilities. Managing Leisure: An International Journal, 4(4), 201-217.

Robinson, L. (2006). Customer expectations of sport organizations. European Sport Management Quarterly, 6(1), 67-84.

Shonk, D. J., \& Chelladurai, P. (2008). Service quality, satisfaction, and intent to return in event sport tourism. Journal of Sport Management, 22(5), 587-602.

Šíma, J., \& Ruda, T. (2011). Customer perception of service quality in sport. Acta Universitatis Carolinae Kinanthropologica (Charles University Journal of Kinanthropology), 47(2), 68-77.

Spreng, R., \& Chiou, J. (2002). A cross-cultural assessment of the satisfaction formation process. European Journal of Marketing, 36(7/8), 1-8.

Spreng, R., \& Mckoy, R. (1996). An empirical examination of a model of perceived service quality and satisfaction. Journal of Retailing, 72(2), 201-214.

Taylor, S., \& Baker, T. (1994). An assessment of the relationship between service quality and customer satisfaction in the formation of consumers' purchase intentions. Journal of Retailing, 70(2), 163-178.

Tian-Cole, S., \& Crompton, J. L. (2003). A conceptualization of the relationships between service quality and visitor satisfaction and their links to destination selection. Leisure Studies, 22(1), 65-80.

Tsitskari, E., Tsiotras, D., \& Tsiotras, G. (2006). Measuring service quality in sport services. Total Quality Management \& Business Excellence, 17(5), 623-631.

Tsuji, Y., Bennet, G., \& Zhang, J. (2007). Consumer satisfaction with an action sports event. Sport Marketing Quarterly, 16(4), 199-208. 
Wisniewski, M. (2001). Using SERVQUAL to assess customer satisfaction with public sector services. Managing Service Quality, 11(6), 380-388.

Woodside, A., Frey, L., \& Daly, R. T. (1989). Linking service quality, customer satisfaction, and behavioural intention. Journal of Health Care Marketing, 9(4), 5-17.

Wright, B. A., Duray, N., \& Goodale, T. L. (1992). Assessing perceptions of recreation center service quality: An application of recent advancements in service quality research. Journal of Park and Recreation Administration, 10(3), 33-47.

Yong, J. K. (2000). A multidimensional and hierarchical model of service quality in the participant sport industry (Unpublished doctoral dissertation, Ohio State University).

Zeithaml, V. A., \& Bitner, M. J. (2003). Services marketing: Integrating customer focus across the firm. New York: McGraw-Hill. 